\title{
PENGARUH PENDAPATAN TERHADAP KONSUMSI DAGING BABI DI KECAMATAN WANEA KELURAHAN RANOTANA WERU
}

\author{
Ridel Keintjem, F. S Oley*, G. D. Lensun*, J. Pandey*. \\ Fakultas Peternakan Universitas Sam Ratulangi Manado, 95115
}

\begin{abstract}
ABSTRAK
Penelitian ini tentang pengaruh pendapatan terhadap konsumsi daging babi di Kelurahan Ranotana WeruKecamatan Wanea. Pada umumnya Masyarakat yang ada di kota Manado terutama di daerah Kelurahan Ranotana Weru Kecamatan Wanea, sebagian besar dapat mengkonsumsi daging babi,namun tidak semuanya mampu membeli karena pendapatan yang rendah. Oleh sebab itu masalahnya adalah apakah pendapatan berpengaruh terhadap konsumsi daging babi dan barang subsitusi di Kelurahan Ranotana Weru Kecamatan Wanea. Penelitian ini Untuk mengetahui pengaruh pendapatan terhadap konsumsi daging babi dan barang subsitusi di Kelurahan Ranotana Weru Kecamatan Wanea. Dalam penelitan ini menggunakan metode survei, dan data yang di peroleh adalah data sekunder dan primer. Penentuan sampel/responden dilakukan secara purposive sampling, dan untuk mengetahui tujuan dari penelitian ini digunakan analisis regresi berganda dengan Rumus sebagai berikut: $C=b_{0}+b_{1} x_{1+} b_{2} x_{2}+$ $\mathrm{b}_{3} \mathrm{x}_{3}$.Hasil analisis pengaruh pendapatanterhadap konsumsi daging babi di Kelurahan Ranotana Weru Kecamatan Wanea dinyatakan dalam persamaan sebagai berikut $: C=59.44+1.38\left(X_{1}\right)+0.018\left(X_{2}\right)+$ $4.97\left(X_{3}\right) R^{2}=0,95$. Berdasarkan hasil persamaan di atas, nampak bahwa nilai intersep sebesar 59,44 menunjukkan bahwa tanpa perubahan harga daging babi, harga barang subsitusi,

*Korespondensi (corresponding Author)

Email: ridelkeintjem@yahoo.com
\end{abstract}

dan pendapatan maka masyarakat di Kelurahan Ranotana Werutetap mengkonsumsi daging babi sebesar 59,44 gram. Melihat nilai koefisien regresi dari harga daging babi sebesar 1,38 gram artinya setiap kenaikanharga daging babi sebesar Rp.1 rupiah maka konsumsi daging babi turun sebesar 1.38 gram. Melihat nilai koefisien regresi dari harga barang subsitusi sebesar 0,018 gram artinya setiap kenaikanharga barang subsitusi sebesar Rp.1 rupiah maka konsumsi barang subsitusi naik sebesar 0,018 gram. Melihat nilai koefisien regresi dari pendapatan sebesar 4,97 artinya setiap peningkatan pendapatan sebesar Rp 1 maka konsumsi akan naik sebesar 4,97 gram. Nilai $\mathrm{R}^{2}$ sebesar 0,95 menunjukkanbahwa variasi naik turunnya konsumsi daging babi danbarang subsitusi, sebesar $95 \%$ dipengaruhi oleh faktor pendapatan keluarga, sisanya 5 \%dipengaruhi oleh faktor lain yang tidak dimasukkan dalam model persamaan tersebut. Pendapatan keluarga berpengaruh nyata terhadap konsumsi daging babi dan barang subsitusi di Kelurahan Ranotana Weru Kecamatan atau signifikan. Hal ini dibuktikan dengan hasil uji t sebesar 0.786 lebih kecil dari $\mathrm{T}_{\text {tabel }} 2.000$

Kata Kunci : Pendapatan, Konsumsi, daging babi, subsitusi 


\section{ABSTRACT}

$\begin{array}{lrr}\text { INCOME } & \text { EFFECT } & \text { ON } \\ \text { CONSUMPTION OF PORK IN } & \text { WANEA } \\ \text { DISTRCT } & \text { RANOTANA } & \text { WERU } \\ \text { VILLAGE } & & \end{array}$

This study aims to determine the effect of family income to the consumption of pork and substitutes, in Wanea district, Ranotana Weru village. The survey method used to obtain secondary data and primary data. Samples were obtained by purposive sampling, and to get answers from the purpose of this study, the formula of multiple regression analysis is used: $\mathrm{C}=\mathrm{b} 0$ $+\mathrm{b} 1 \mathrm{x} 1+\mathrm{b} 2 \times 2+\mathrm{b} 3 \times 3$, and obtained the analysis of the influence of family income on the consumption of pork in Ranotana Weru village as the following: $\mathrm{C}=59.44+$ $1.38(\mathrm{x} 1)+0,018(\mathrm{x} 2)+4.97(\mathrm{x} 3) \mathrm{R} 2=$ 0.95 . From the results of the equation, the value of the intercept of 59.44 indicates that no change in the price of pork, the price of substitutes and without changes in income, then the people in Ranotana Weru village keep eating pork amounted to 59.44 grams (per person?). See the regression coefficient value of the price of pork of 1.38 , meaning in any increase in the price of pork $\mathrm{Rp}$ 1.000 , the consumption of pork decreased by 1.38 grams (per person?), Seethe price regression coefficient value of substitutes 0.018 , means any increase in the price of substitutes $\mathrm{Rp} 1.000$, the substitution of consumption goods rose by 0,018 grams. See the earnings darai regression coefficient 4.97 , meaning any increase in revenue to $\mathrm{Rp} 1.000$, the consumption of pork will rise by 4.97 grams and R2 value of 0.95 indicates that variations in rise and fall of the consumption of pork and substitutes at $95 \%$ influenced by factors family income and sisnya $5 \%$ influenced by other factors not included in the model equations. Family income significantly affect the consumption of pork and substitutes in the village ranotana Weru. This is evidenced by the results of the $t$ test of 0.786 is smaller than Ttabel 2,000.

Keywords: Income, consumption of pork, substitutes

\section{PENDAHULUAN}

Tujuan pembangunan Nasional adalah untuk mencapai masyarakat adil dan makmur, manusianya sehat, kuat dan cerdas, dengan terbentuk manusia yang sehat dan cerdas pasti akan mempengaruhi pola makanan yang dikonsumsinya, dan jika makanan tersebut memenuhi standar gizinya maka akan tercapailah tujuan dari pembangunan Nasional untuk membentuk manusia yang sehat, kuat, dan cerdas, tetapi bila makanan yang dikonsumsinya tidak memenuhi standar gizi, maka tujuan tersebut tidak dapat dicapai.Salah satu upaya meningkatkan konsumsi protein asal ternak adalah meningkatkan kontribusi produksi peternakan baik berupa daging, susu dan telur,dalam rangka mendukung perkembangan sektor peternakan,pemerintah telah menyusun berbagai langkah kebijakan, antara lain memacu pembangunan peternakan dengan meningkatkan perannya sebagai penghasil protein hewani yang bernilai tinggi melalui peningkatan produksi protein asal ternak (Rahardi, 2003). Permintaan (Demand) adalah jumlah barang 
yang diminta oleh konsumen pada suatu pasar.Sebagianahli mengatakan bahwa pengertian permintaan adalah jumlah barang yang sanggup dibeli oleh para pembeli pada suatu tempat dan waktu tertentu dengan harga yang berlaku pada saat itu.Tenaga beli seseorang tergantung atas dua unsur pokok yaitu pendapatan yang dibelanjakan dan harga barang yang dikehendaki.Menurut Sukirno (2002), Hukum Permintaan pada hakekatnya merupakan suatu hipotesis yang menyatakan: "Semakin rendah harga suatu barang maka semakin banyak permintaan terhadap barang tersebut".Konsumsi sangat berpengaruh terhadap stabilitas prekonomian, Semakin tinggi tingkat konsumsi, semakin tinggi pula perubahan kegiatan ekonomi.Pada umumnya masyarakat yang ada di Manado terlebih di daerah Kelurahan Ranotana Weru Kecamatan Wanea, banyak yang mengkonsumsi daging babi, tapi tidak semua masyarakat bisa mengonsumsi karena pendapatan yang rendah, dan daging babi tersebur hanya bisa dikonsumsi oleh yang beragama non Muslim saja. Melihat keadaan tersebut, permasalahannya Apakah pendapatan keluarga berpengaruh terhadap konsumsi daging babi dan barang subsitusi di Kelurahan Ranotana Weru Kecamatan
Wanea. Tujuan penelitian ini Untuk mengetahui pengaruh pendapatan keluarga terhadap konsumsi daging babi dan barang subsitusi di Kelurahan Ranotana Weru Kecamatan Wanea.

\section{METODE PENELITIAN}

Penelitian ini telah dilaksanakan di kota Manado Kelurahan Ranotana Weru Kecamatan Wanea selama 1 bulan mulai tanggal 13 Mei sampai tanggal 13 Juni 2015.Penelitian ini menggunakan metode survey, Menurut Singarimbun dan Effendi (1989).Data yang diperoleh adalah data primer dan sekunder.Data primer diperoleh langsung dari responden melalui wawancara dengan menggunakan daftar pertanyaan. Data sekunder diperoleh dari instansi terkait yaitu Kantor Kecamatan Wanea, dan Kantor Kelurahan Ranotana Weru.Penentuan lokasi ini dilakukan secara "purposive sampling", berdasarkan pertimbangan yaitu : 1 . Kelurahan ini populasi penduduk yang beragama non muslim terbanyak dengan asumsi penduduk tersebut dapat mengkonsumsi daging babi, 2. Populasi yang dipilih dekat dengan pasar tradisional (pasar pinasungkulan).Selanjutnya daging babi adalah semua bagian karkas ternak babi). Jumlah sampel yang terpilih dapat dilihat pada Tabel 1 . 
Tabel 1. Penentuan jumlah sampel di Kelurahan Ranotana Weru Kecamatan. Wanea

\begin{tabular}{ccccc}
\hline No. & Lingkungan & $\begin{array}{c}\text { JumlahPenduduk } \\
\text { beragama Kristen }\end{array}$ & $\begin{array}{c}\text { Jumlah Keluarga } \\
\text { beragama Kristen }\end{array}$ & $\begin{array}{c}\text { Jumlah } \\
\text { sampel }\end{array}$ \\
\hline 1 & 1 & 864 & 144 & 5 \\
2 & 2 & 761 & 126 & 4 \\
3 & 3 & 667 & 111 & 4 \\
4 & 4 & 945 & 157 & 6 \\
5 & 5 & 659 & 109 & 4 \\
6 & 6 & 574 & 95 & 3 \\
7 & 7 & 633 & 105 & 4 \\
8 & 8 & 745 & 124 & 4 \\
9 & 9 & 1097 & 182 & 8 \\
10 & 10 & 1096 & 182 & 8 \\
\hline \multicolumn{7}{l}{ Total sampel } & 50 & & & \\
\hline
\end{tabular}

Definisi Variabel Dan Pengukurannya, 1. Pendapatan keluarga adalah jumlah penerimaanseluruh anggota rumah tangga selama satu bulan, di ukur dalam satuan rupiah/bulan.2.Konsumsi daging babiadalah jumlah daging babi yang dibeli dan dikonsumsi selama 1 bulan untuk seluruh anggota keluarga, dinyatakan dalam satuan kg per bulan.3.Konsumsi barang subsitusi (ikan) adalah jumlah barang subsitusi yang di beli dan di konsumsi selama 1 bulan untuk seluruh anggota keluarga, dinyatakan dalam satuan $\mathrm{kg}$ per bulan.Metode Analisis yang digunakan adalah analisis regresi berganda dan analisis deskriptif, (Sulaiman 2004), Sukmadinata, (2011)

\section{HASIL DAN PEMBAHASAN}

Keadaan umum lokasi penelitian, Kelurahan Ranotana Weru adalah salah satu kelurahan yang ada di Kecamatan Wanea kota Manado. Jumlah agama yang adalah di Kelurahan Ranotana Weru ada 4 agama yaitu : Kristen, Islam, Katolik, dan Budha, dengan jumlah yang beragama Kristen 7878 jiwa, Islam 563, Katolik 859, dan Budha 3 jiwa, yang memiliki wilayah 64,75 $\mathrm{Ha}$ dengan jumlah KK 1830 dan jumlah penduduk secara keseluruhan 9302 jiwa, (Kantor Kelurahan Ranotana Weru 2015). 
Tabel 2. Jumlah Responden dan konsumsi daging babi berdasarkan tingkat pendapatan

\begin{tabular}{lcc} 
Keluarga & & \\
\hline Pendapatan $(\mathrm{Rp} / \mathrm{B} \ln )$ & Jumlah Responden $($ Org $)$ & jumlah konsumsi (Kg/bln) \\
\hline $2.500 .000-3.500 .000$ & 12 & 14 \\
$3.510 .000-4.500 .000$ & 25 & 29,5 \\
$4.510 .000 .-6.500 .000$ & 13 & 17 \\
\hline Jumlah & 50 &
\end{tabular}

Sumber: data di olah 2015

Tabel 3. Jenis daging babi yang dikonsumsi oleh responden

\begin{tabular}{lcc}
\hline Jenis daging babi & Jumlah Responden (org) & Persentase (\%) \\
\hline Daging babi khas dalam/luar & 40 & 80,00 \\
Daging babi campuran tulang & 2 & 4,00 \\
Tulang rusuk & - & - \\
Tulang kaki & - & - \\
Tulang belakang & - & - \\
Daging babi lapis & 8 & 16,00 \\
Jeroam & - & - \\
\hline Jumlah & 50 & 100,00 \\
\hline
\end{tabular}

Sumber: data di olah 2015

\section{Pendapatan responden}

Tabel 2 menunjukan bahwa sebagian besar keluarga responden yang memiliki pendapatan sebesar 3.510.000-.4.500.000 per bulan sebanyak 25 keluarga $(50,00 \%)$, pendapatan responden 2.500.000 - 3.500.000 per bulan sebanyak 12 (24,00\%), dengan melihat perbedaan tingkat pendapatan dari responden yang berada di Kelurahan Ranotana Weru Kecamatan Wanea, tentu saja akan berdampak pada setiap pembelian daging babi setiap bulannya.. Rata-rata pendapatan responden dalam penelitian per bulan sebesar Rp 2.544.000, di bandingkan dengan hasil penelitian dari Heriyon dan
Hidayati (2008) rata-rata per bulan sebesar Rp 982.054, masih lebih rendah. Menurut Giang (2013) bahwa tingkat pendapatan berhubungan erat dengan pola konsumsi.

\section{Konsumsi daging babi}

Jenis daging babi yang di konsumsi oleh responden dapat di lihat pada Tabel 3.

Dari data Tabel 3 menunjukan bahwa dari semua jenis daging babi, yang paling digemari adalah jenis daging babi khas dalam dan luar karena jenis daging ini empuk dan enak di bandingkan dengan yang lainnya, hal ini dapat di lihat bahwa responden yang mengkonsumsi jenis daging babi khas dalam/luar sebanyak 40 responden 
(80,00\%) sedangkan yang paling sedikit dikonsumsi adalah campuran tulang sebanyak 2 responden (4,00\%).Menurut Amir et al. (2006) yang menyatakan bahwa peningkatan harga daging akan berpengaruh terhadap konsumsi daging babi.Hasil analisis rata-rata konsumsi daging babi/kapita/bulan di Kelurahan Ranotana Weru Kecamatan Wanea yaitu sebesar 1,25 $\mathrm{kg} / \mathrm{kapita} /$ bulan. Di bandingkan dengan hasil penelitian dari Osak, (2014) bahwa konsumsi daging (daging sapi, babi, dan ayam) per kapita $2.10 \mathrm{~kg}$. Menurut Weol (2014) rata-rata konsumsi daging kapita/tahun sebesar 7,7 kg. MenurutHennebery danHwang (2007) tentang konsumsi daging di Korea Selatanmasyarakatyang mengindikasikan adanya peningkatan konsumsi daging seiringdengan waktu dan perubahan gaya hidup masyarakat di negara-negara tersebut.

$$
\text { Hasil analisis pengaruh }
$$

pendapatanterhadap konsumsi daging babi di Kelurahan Ranotana Weru Kecamatan Wanea dinyatakan dalam persamaan sebagai berikut $\mathrm{C}=59.44+1.38 \mathrm{X}_{1}+0.018 \mathrm{X}_{2}+4.97 \mathrm{X}_{3}$ $\mathrm{R}^{2}=0,95$

Berdasarkan hasil persamaan di atas, nampak bahwa nilai intersep sebesar 59,44 menunjukkan bahwa tanpa perubahan harga daging babi, harga barang subsitusi, danpendapatan maka masyarakat di Kelurahan Ranotana Werutetap mengkonsumsi daging babi sebesar 59,44 gram. Namun melihat nilai koefisien regresi dari harga daging babi sebesar 1,38 gram artinya setiap kenaikanharga daging babi sebesar Rp.1.000rupiah maka konsumsi daging babi menurun sebesar 1.38 gram. Melihat nilai koefisien regresi dari harga barang subsitusi sebesar 0,018 gram artinya setiap kenaikanharga barang subsitusi sebesar Rp.1.000rupiah maka konsumsi barang subsitusi naik sebesar 0,018 gram. Melihat nilai koefisien regresi dari pendapatan sebesar 4,97 artinya setiap peningkatan pendapatan sebesar Rp 1.000 maka konsumsi akan naik sebesar 4,97 gram. Nilai $\mathrm{R}^{2}$ sebesar 0,95 menunjukkanbahwa variasi naik turunnya konsumsi daging babi danbarang subsitusi, sebesar $95 \%$ dipengaruhi oleh faktor pendapatan keluarga, sisanya $5 \%$ dipengaruhi oleh faktor lain yang tidak dimasukkan dalam model persamaan tersebut.

Hasil uji $\mathrm{T}$ daging babi bernilai negatif sebesar 0.786 , lebih kecil dari $t_{\text {tabel }}$ 2.000. Angka ini menunjukan bahwa pendapatan berpengaruh terhadap konsumsi daging babi di Kelurahan Ranotana Weru Kecamatan Wanea. Hal ini menunjukan 
bahwa $\mathrm{H}_{1}$ di tolak yang artinya bahwa pendapatan berpengaruh nyata terhadap konsumsi daging babi dan barang subsitusi. Hasil ini di tunjang oleh penelitian Ambat (2011) tentang Analisis konsumsi daging yang menunjukan bahwa pendapatan berpengaruh nyata terhadap konsumsi daging babi dan barang subsitusi.

(Uji F) berdasarkan hasil perhitungan dengan tingkat kepercayaan 95\% diperoleh $F_{\text {hitung }}$ 346.34> $F_{\text {tabel }}$ 5.79. dan nilai signifikan 1,44 lebih besar dari taraf signifikan 0.05 ( sig >0.05) maka dapat disimpulkan H1 diterima, yang artinya bahwa pendapatan memiliki pengaruh yang nyata atau signifikan terhadap ke dua variabel ini, (konsumsi daging babi dan barang subsitusi).

\section{KESIMPULAN}

Berdasarkan hasil penelitian dapat disimpulkan Pendapatan keluarga berpengaruh nyata terhadap konsumsi daging babi dan barang subsitusi di Kelurahan Ranotana Weru Kecamatan atausignifikan.Hal ini dibuktikan dengan hasil uji t sebesar 0.786 lebih kecil dari $\mathrm{T}_{\text {tabel }}$ 2.000 .

\section{DAFTAR PUSTAKA}

Amir A., S. Widodo, dan S. Haryastuti. 2006. Analisi konsumsi daging sapi padatingkat rumah tangga di SulawesiTengah. Jurnal Agrosaint. 19(4):435-449.

Ambat, A.G 2011. Analisis konsumsi daging di Kecamatan Tikala Kota Manado. Skripsi. Fakultas Peternakan Unsrat. Manado.

Giang, R.R. 2013. Pengaruh Pendapatan Terhadap Konsumsi Buruh Bangunan di Kecamatan Pineleng. Jurnal EMBA Vol 1 (3) : 248-256.

Hennebery S.R. and S. Hwang, 2007. Meat Demand in South Korea:An Application of the Restricted SourceDifferentiated Almost Ideal Demand System Model. Journal of Agricultural and Applied Economics. 39(1), 47-60.

Heriyon. Z dan hidayati. 2008. Analisis faktor-faktor yang mempengaruhi konsumsi daging ayam broiler masyarakat kecamatan tembilahan kabupaten indragiri hilir.Fakultas Pertanian dan Peternakan Universitas Islam NegeriSultan SyarifKasim Riau. Jumal Peternakan Vol 5 (2) : 61 - 70

Osak, R, Paneleween, Pandey,Lumenta 2014. Pengaruh pendapatan rumah tangga terhadap konsumsi daging 
sapi, babi dan ayam) di desa sea

kecamatan pineleng.. Jurnal

Zootek Vol 34 (2) : 10-17

Rahardi, F. dan Hartono, R. 2003. Agribisnis Peternakan. Penerbit Penebar Swadaya,Depok

Singarimbun, M., Effendi, S, 1989, Metode

Penelitian Survey, PT. Pustaka LP3ES Indonesia, Jakarta.

Sukirno. 2002. MikroEkonomi Teori Pengantar. PT Raja Graha Persada. Jakarta.

Sulaiman,W. 2004 Analisis regresi. Andi Offset Yogyakarta

Sukmadinata, N. S, 2011. Metode Penelitian Pendidikan. Cetakan ke 7. Bandung : Remaja Rosdakarya.

Weol. Elvis . F, Rorimpandey, Lenzun, Endoh 2014. Analisis pengaruh pendapatan rumah tangga terhadap konsumsi daging dan telur di kecamatan suluun tareran kabupaten minahasa selatan. Jurnal Zootek Vol 34 (1) :37-47 